\title{
A new species of Cyrtandra (Gesneriaceae) from Aceh, Sumatra
}

\author{
Smith P.E. ${ }^{1}$, Bramley G.L.C. ${ }^{2}$, Kartonegoro A. ${ }^{3}$ \& H.J. Atkins ${ }^{1 *}$ \\ ${ }^{1}$ Royal Botanic Garden Edinburgh, 20A Inverleith Row, Edinburgh EH3 5LR, Scotland, UK. \\ 2 Herbarium, Royal Botanic Gardens, Kew, Richmond, Surrey, TW9 3AE, UK. \\ ${ }^{3}$ Research Centre for Biology, Indonesian Institute of Sciences (LIPI), Jl Jakarta-Bogor, KM. 46, Cibinong - 16911, Indonesia. \\ *E-mail: hatkins@rbge.org.uk
}

\begin{abstract}
A new species of Cyrtandra (Gesneriaceae) from Aceh, Sumatra, C. rubriflora P.E.Sm. \& H.J.Atkins, is described and illustrated. Based on IUCN criteria, C. rubriflora is assessed as Near Threatened (NT).
\end{abstract}

Keywords: Aceh, Cyrtandra, Gesneriaceae, New species, Sumatra.

\section{Introduction}

Cyrtandra J.R. Forst. \& G. Forst. is the largest genus in the Gesneriaceae, recently estimated to contain c. 800 species and characterised by high levels of narrow endemism (Atkins et al., 2013). It is found from the Nicobar Islands in the Indian Ocean, throughout Malesia, in Taiwan and the southern Japanese islands, in northern Australia and across the Pacific as far east as the Marquesas and North to Hawaii. It is recorded on the Asian continent only as far North as central Thailand (Atkins et al., 2013) with centres of diversity in Borneo, New Guinea and the Pacific Islands (Burtt, 2001). There are currently 62 recognised species of Cyrtandra in Sumatra (Bramley \& Cronk, 2003).

The equatorial island of Sumatra with an area of $476,000 \mathrm{~km}^{2}$, is the second largest in the Malesian region (Laumonier et al., 2010). It is dominated by the $1,700 \mathrm{~km}$ long Barisan mountain range which runs along the west coast. It is species-rich with an estimated 10,000 species of higher plants (Whitten et al., 2000). The island is an area of high anthropogenic pressure where both lowland and

Received: 05.11.2019; Revised \& Accepted: 17.03.2020

Published Online: 11.05.2020 upland vegetation have been extensively cleared. The new species described here grows in Aceh province in lowland forest (as defined by Cannon et al., 2009). Research on Cyrtandra in Sumatra has resulted in the discovery of this distinctive, redflowered species from this province.

\section{Materials and Methods}

Herbarium specimens from ANDA, BO, E, K, L, SING were examined during an ongoing research project on the taxonomy of Sumatran Cyrtandra (Herbarium acronyms follow Thiers (continuously updated). Material from ANDA was examined electronically. Other materials were examined and compared using a stereomicroscope and flowers were dissected after boiling (Bridson \& Forman, 1999). Colour and shape descriptions were recorded from digital photographs taken in the field. Detailed examination of all of the material available and comparison with type specimens and protologues of Sumatran species and those of neighbouring areas (Jack, 1823; Clarke, 1883; Ridley, 1917; Bakhuizen van den Brink, 1950; Bramley \& Cronk, 2003; Bramley et al., 2004) was carried out in order to confirm that this species is new.

Cyrtandra rubriflora P.E.Sm. \& H.J.Atkins, sp. nov.

Figs. $1 \& 2$

This species is similar to the widespread C. picta Blume in being a herb with subsessile inflorescences and large, slightly connate bracts that enclose the base of the inflorescence, and a glabrous ovary. It differs in corolla colour (dark pink to red $v$ s white, cream or pale yellow 


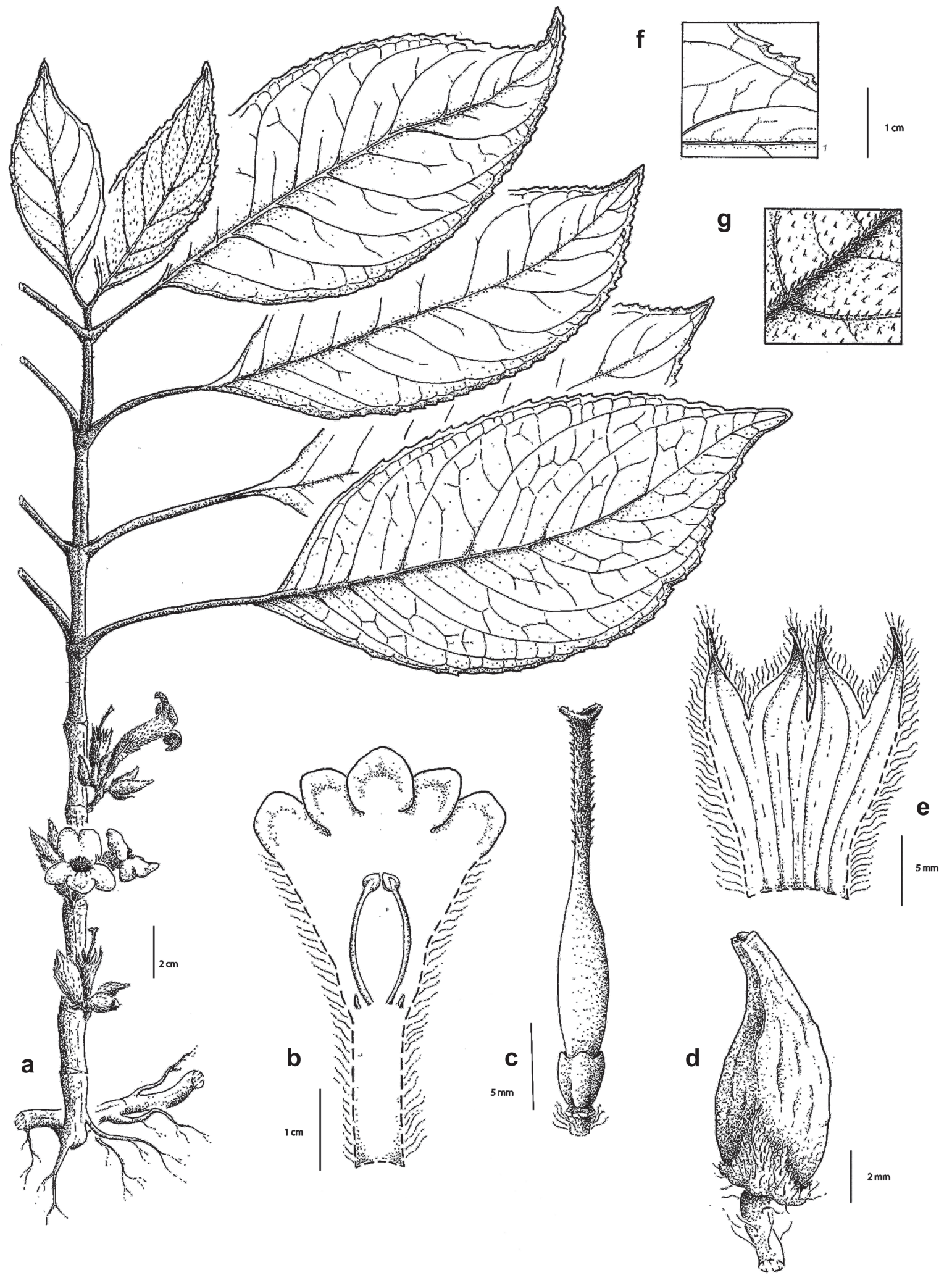

Fig. 1. Cyrtandra rubriflora P.E.Sm. \& H.J.Atkins: a. Habit; b. Corolla opened to show position of stamens and staminodes; c. Gynoecium; d. Immature fruit; e. L.S. of the calyx showing the ventral surface; $f$. Detail of upper leaf surface; $\mathbf{g}$. Detail of lower leaf surface (a-c \& e-g from P. Wilkie, M. Hughes, A. Sumadijaya, S. Rasnovi, Marlan \& Rabusin PW603; d from P. Wilkie, M. Hughes, A. Sumadijaya, S. Rasnovi, Marlan \& Rabusin PW630; drawn by Rebecca Camfield). 

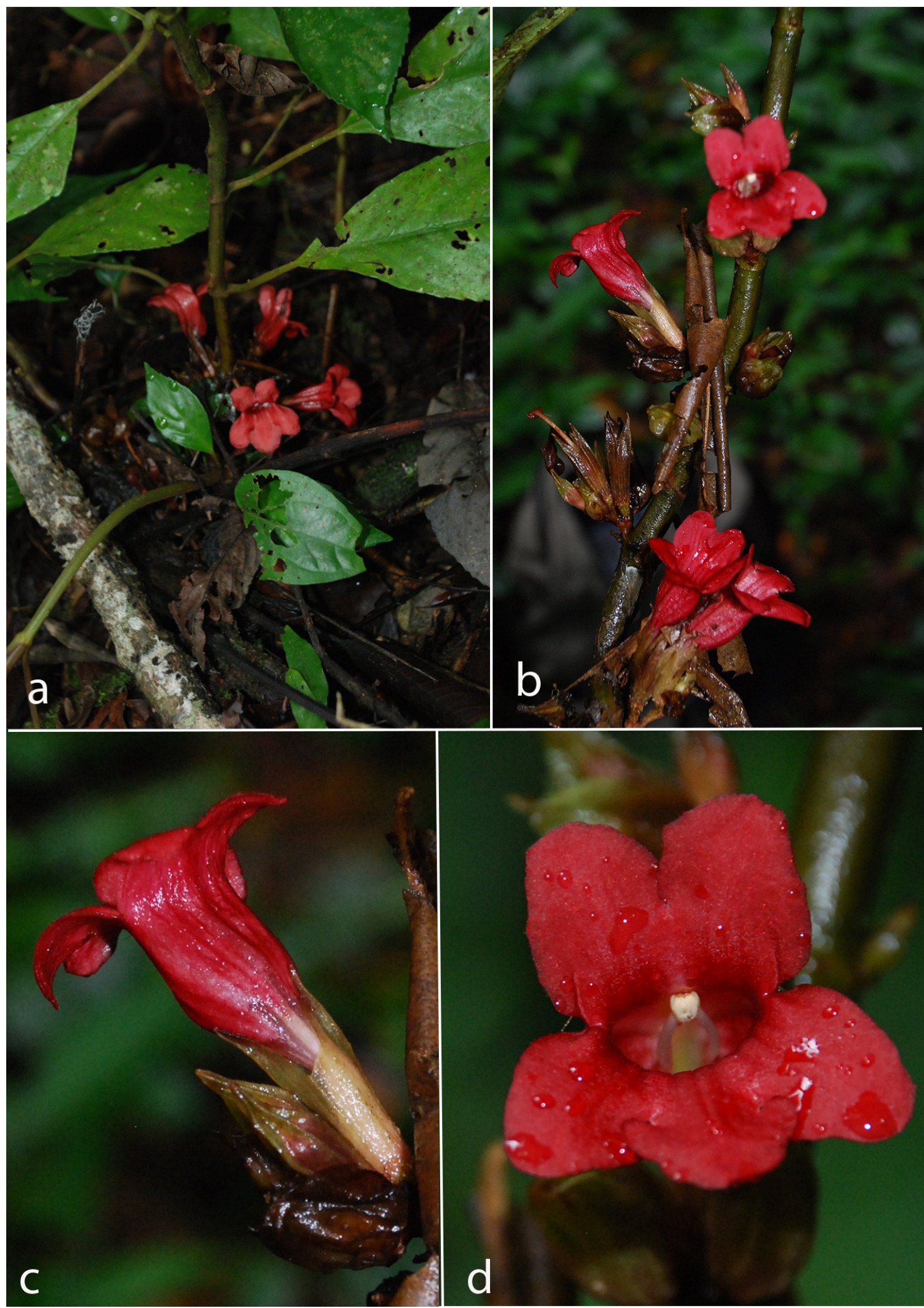

Fig. 2. Plate of Cyrtandra rubriflora P.E.Sm. \& H.J.Atkins: a. Habit; b. Inflorescence; c. Flower-lateral view; d. Flower-front view (photos by Peter Wilkie). 
with purple dots in the throat); leaf shape (elliptic $v s$ ovate) and anther indumentums (glabrous $v s$ with a short tuft of simple hairs at the tips and along the connective).

Type: INDONESIA, Sumatra, Aceh, Gunung Leuser National Park, Ketambe Research Station, 08.03.2008, P. Wilkie, M. Hughes, A. Sumadijaya, S. Rasnovi, Marlan \& Rabusin PW630 (holo E [E00416358!]; iso BO [BO1880564!]).

Erect herbs $30-100 \mathrm{~cm}$ tall. Stems terete to quadrangular, striate, glabrate. Leaves opposite and subequal, some pairs slightly anisophyllous. Petiole 4-10 cm long, sparsely hairy, more densely so when young, hairs simple and matted. Blade elliptic, 6.0$9.5 \times 14-21 \mathrm{~cm}$, base cuneate, somewhat soblique, apex acuminate, 8-20 mm long, margins serrate, upper surface more or less glabrous, lower surface with a sparse covering of simple hairs (c. $1 \mathrm{~mm}$ long), dense over midrib and veins, lateral leaf vein pairs 6-7. Inflorescence axillary, subsessile or shortly pedunculate, occurring from base of plant to about half way up the stem, usually below the leaves, four or more flowers per inflorescence; bracts $c .13 \mathrm{~mm}$ long, enclosing the base of the inflorescence, dark green to brown, with an indumentum of simple, matted hairs less than $1 \mathrm{~mm}$ long. Peduncles 2-3 $\mathrm{mm}$ long with dense, simple, matted hairs $c .1 \mathrm{~mm}$ long. Pedicels 2-3 mm long. Calyx yellow-green somewhat translucent, turning brown with maturity, tubular, 15-20 mm long, lobes four or five, narrowly acuminate, 2-3 mm long, externally with c. 1-3 mm long simple hairs, internally glabrous. Corolla dark pink to red, 43-50 mm long, tube narrow whilst within the calyx, widening to mouth, somewhat compressed laterally, lobes spreading, slightly recurved, posterior lobes $c .11 \times$ $8 \mathrm{~mm}$, lateral lobes $c .8 \times 6 \mathrm{~mm}$ and anterior lobe 8 $\times 8 \mathrm{~mm}$, externally with 4-7 $\mathrm{mm}$ long simple hairs, internally glabrous. Stamens 2 , white, filaments 10 $12 \mathrm{~mm}$ long, glabrous; anthers creamy-yellow 2$2.5 \mathrm{~mm}$ long, face to face and cohering at tips, thecae distally confluent, but proximally separate, glabrous; lateral staminodes $1.5 \mathrm{~mm}$ long, posterior staminode not seen. Gynoecium $22 \mathrm{~mm}$ long, disk cupular, $2 \mathrm{~mm}$ long, glabrous, with an undulate margin; ovary glabrous, style white with short, 0.5 $\mathrm{mm}$ hairs distally; stigma bilobed. Fruit ovoid, somewhat scabrous, c. $10 \times 4 \mathrm{~mm}$, base of style and calyx persistent, glabrous, immature.

Flowering \& fruiting: From January to May (based on limited material available).

Habitat: Lowland forest, often riparian, 200-400 m elevation.

Distribution: Sumatra, Aceh province (Fig. 3).

Etymology: The specific epithet refers to its unusual red flowers.

Specimens examined: INDONESIA, Sumatra, Aceh Province, Gunung Leuser National Park, Valley of Lau Alas, 17.05.1972, W.J.J.O. de Wilde \& B.E.E. de Wilde-Duyfjes 12059 (K, L); Jantho Pinus Nature Reserve, Nangroe Aceh Darussalam, forest area of Sumatran Orangutan Reintroduction Program (SOCP), 12.01.2017, Nurainas \& Rezi NAS-3450 (ANDA); Ketambe Research Station, 06.03.2008, P. Wilkie, M. Hughes, A. Sumadijaya, S. Rasnovi, Marlan \& Rabusin PW603 (E [E00416326!]).

Conservation status: Cyrtandra rubriflora has been collected on three separate botanical expeditions between 1972 and 2017. Three of the four collections were made close together in Gunung Leuser National Park which straddles the borders of Aceh and North Sumatra provinces. The fourth collection is from Pinus Jantho Nature Reserve which is approximately $275 \mathrm{~km}$ to the north. The species has an EOO of $658 \mathrm{~km}^{2}$ and an AOO of 12 $\mathrm{km}^{2}$ based on a $2 \times 2 \mathrm{~km}$ grid cell size under the $\mathrm{B}$ criteria (Bachman et al., 2011). The flora of the region is relatively poorly known and it is possible that further collecting will expand the range of $C$. rubriflora. The threat of habitat loss in the forest regions of Sumatra, however, is well documented and is particularly acute for lowland species. One estimate indicates that the island has lost nearly half of its forests in the past 15 years alone and it seems that designation of protected areas has not been totally successful in preventing logging and deforestation within their boundaries (Gaveau et al., 2009, Global Conservation, 2017). Three collections were made in Gunung Leuser National 


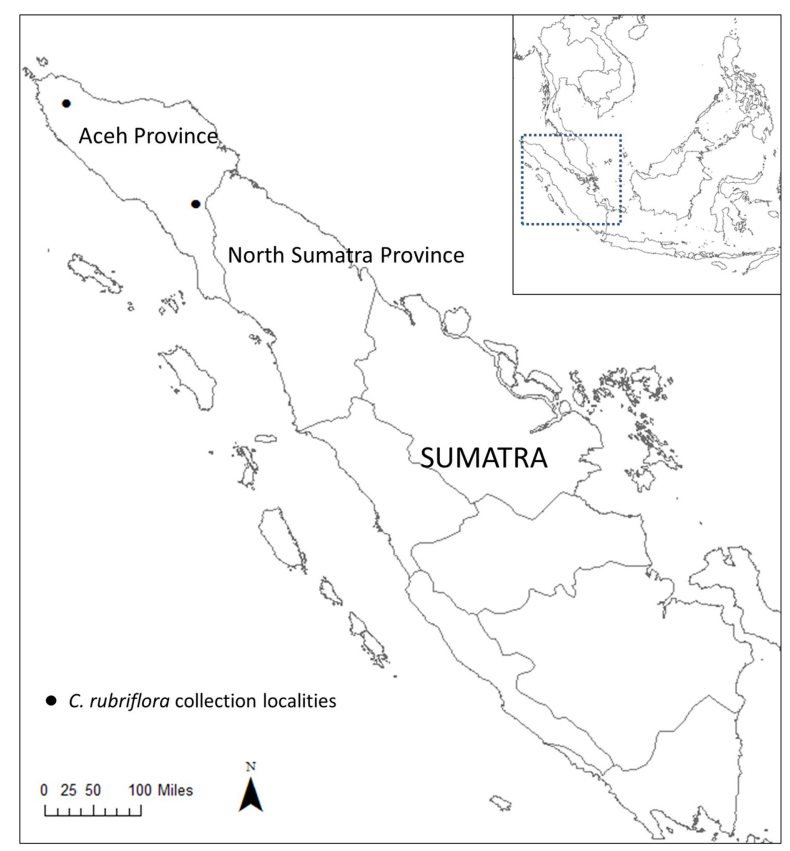

Fig. 3. Distribution of Cyrtandra rubriflora P.E.Sm. \& H.J.Atkins.

Park which is known to be suffering from forest degradation and loss of habitat through illegal logging and encroachment. Areas adjacent to the park have been extensively cleared for palm oil plantations (UNESCO, 2012). It can therefore be considered likely that the habitat of C. rubriflora is threatened. Based on the small number of collections and our knowledge of the widespread deforestation and forest conversion in the area we would recommend a cautious listing for this species under Near Threatened (NT) as per guidelines for using IUCN Red list categories and criteria (2019) and emphasise the need for further collecting in the area.

Notes: Cyrtandra rubriflora is similar to the widespread and morphologically variable species C. picta but there are important differences that allow these two species to be easily distinguished and that are detailed in the diagnosis. Red-flowered species are unusual in Cyrtandra, especially in western Malesia where the majority of species have white flowers (Bramley \& Cronk, 2003; Bramley et al., 2004; Atkins et al., 2013). There are only three other species from Sumatra that are described as having purplish or reddish flowers. They are all very distinct from C. rubriflora; C. frutescens Jack and C. rubiginosa Jack have cylindrical fruits and small, linear inflorescence bracts and C. rosea Ridl. can be distinguished by being a woody shrub with smaller flowers (20 mm long as opposed to $43-50 \mathrm{~mm}$ long), decurrent leaf bases and a hairy ovary.

\section{Acknowledgements}

We would like to thank Rebecca Camfield for her illustration and Peter Wilkie (RBGE) for photographs. In Indonesia we would like to acknowledge the ongoing support of RISTEKDIKTI, the Indonesian Ministry of Forestry and staff at the Kebun Raya Bogor, Herbarium Bogoriense and Andalas University. The Royal Botanic Garden Edinburgh is supported by the Rural and Environment Science and Analytical Services Division (RESAS) of the Scottish Government.

\section{Literature Cited}

ATKINS H., BRAMLEY G. \& J.R. CLARK 2013. Current knowledge and future directions in the taxonomy of Cyrtandra (Gesneriaceae), with a new estimate of species numbers. Selbyana 31: 157-165.

BACHMAN S., MOAT J., HILL A.W., TORRE J. DE LA \& B. SCOTT 2011. Supporting Red List threat assessments with GeoCAT: geospatial conservation assessment tool. ZooKeys 150: 117-126. https://doi.org/ 10.3897/zookeys.150.2109

BAKHUIZEN VAN DEN BRINK R.C. 1950. Notes on the flora of Java. VI. Blumea 6: 363-406.

BRAMLEY G. \& Q.C.B. CRONK 2003. The Cyrtandra (Gesneriaceae) species of Mount Kerinci, Sumatra. Harvard Papers in Botany 7: 407-421.

BRAMLEY G.L.C., WEBER A. \& Q.C.B. CRONK 2004. The Cyrtandra (Gesneriaceae) species of Peninsular Malaysia and Singapore. Edinburgh Journal of Botany 60: 331-360. https://doi.org/10.1017/S0960428603000283

BRIDSON D. \& L. FORMAN 1999. The Herbarium Handbook. Third Edition. Kew Publishing, Royal Botanic Gardens, Kew.

BURTT B.L. 2001. A survey of the genus Cyrtandra (Gesneriaceae). Phytomorphology 51: 393-404.

CANNON C.H., MORLEY R.J. \& A.B. BUSH 2009. The current refugial rainforests of Sundaland are 
unrepresentative of their biogeographic past and highly vulnerable to disturbance. Proceedings of the National Academy of Sciences 106: 11188-11193. https://doi.org/ 10.1073/pnas.0809865106

CLARKE C.B. 1883. Cyrtandreae (Gesneracearum tribus). In: DE CANDOLLE A. \& C. DE CONDOLLE (eds.), Monographiae Phanerogamarum. Volume 5. Paris: Sumptibus G. Masson, Paris. pp. 1-303.

GAVEAUD.L., EPTING J., LYNE O., LINKIE M., KUMARA I., KANNINEN M. \& N. LEADERWILLIAMS 2009. Evaluating whether protected areas reduce tropical deforestation in Sumatra. Journal of Biogeography 36: 21652175. https://doi.org/10.1111/j.1365-2699.2009.02147.x

GLOBAL CONSERVATION 2017. http://global conservation.org/projects/leuser-national-parkindonesia. (Accessed on 20.06.2017).

\section{IUCN STANDARDS AND PETITIONS COMMITTEE} 2019. Guidelines for Using the IUCN Red List Categories and Criteria. Version 14. Prepared by the Standards and Petitions Committee. Available at: http:// www.iucnredlist.org/documents/RedListGuidelines.pdf (Accessed on 10.12.2019).

JACK W. 1823. II. On Cyrtandraceæ, a new natural order of plants. Transactions of the Linnean Society of London 14(1): 23-45.

LAUMONIER Y., URYU Y., STÜWE M., BUDIMAN A., SETIABUDI B. \& O. HADIAN 2010. Eco-floristic sectors and deforestation threats in Sumatra: identifying new conservation area network priorities for ecosystembased land use planning. Biodiversity and Conservation 19(4): 1153-1174. https://doi.org/10.1007/s10531-0109784-2

RIDLEY H.N. 1917. Results of an expedition to Korinchi Peak, Sumatra. Journal of the Federated Malay States Museums 8(4): 13-135.

THIERS B. (continuously updated). Index Herbariorum: A global directory of public herbaria and associated staff. New York Botanical Garden's Virtual Herbarium. Available at: http://sweetgum.nybg.org/ih (Accessed 04.11.2019).

UNESCO 2012. Saving the Heritage of Gunung Leuser National Park, Tropical Rainforest Heritage of Sumatra. UNESCO, Jakarta.

WHITTEN A.J., DAMANIK S.J., ANWAR J. \& N. HISYAM 2000. The ecology of Sumatra. Oxford University Press, Oxford. 